\title{
Genistein protects against polycyclic aromatic hydrocarbon-induced oxidative DNA damage in non-cancerous breast cells MCF-10A
}

\author{
Hau Y. Leung ${ }^{1}$, Lai Hang Yung ${ }^{2}$, Ching Ho Poon $^{2}$, Guoli Shi ${ }^{3}$, A.-Lien Lu ${ }^{3}$ and Lai K. Leung ${ }^{1,4} *$ \\ ${ }^{1}$ Food and Nutritional Sciences Programme, The Chinese University of Hong Kong, Shatin, N.T., Hong Kong \\ ${ }^{2}$ Molecular Biotechnology Programme, The Chinese University of Hong Kong, Shatin, N.T., Hong Kong \\ ${ }^{3}$ Department of Biochemistry and Molecular Biology, Greenebaum Cancer Center, School of Medicine, University of Maryland, \\ Baltimore, MD 21201, USA \\ ${ }^{4}$ Department of Biochemistry, Room 507C, MMW Building, The Chinese University of Hong Kong, Shatin, N.T., Hong Kong \\ (Received 5 November 2007 - Revised 31 March 2008 - Accepted 7 April 2008 - First published online 23 June 2008)
}

Polycyclic aromatic hydrocarbons (PAH) are established cancer initiators that can be found in our food and environment. Some dietary phytochemicals are strong inhibitors of PAH-induced mutagenesis. The soya isoflavone genistein has been shown previously in our laboratory to be an inhibitor of PAH metabolite binding to DNA. In the present study, we investigated the effect of genistein on oxidative DNA damage induced by PAH in the non-tumorigenic breast cell line MCF10A. 7,12-Dimethyl-benz[ $a$ ]anthracene (DMBA) can induce expressions of CYP1A1 and CYP1B1 which are known to be responsive to PAH. These enzymes, in turn, will metabolise the PAH into their ultimate carcinogenic forms. Genistein can significantly suppress the expressions within $5 \mu \mathrm{M}$. The comet assay indicated that DMBA introduced DNA damage to these cells, and co-treatment with genistein at 5 or $10 \mu \mathrm{M}$ could alleviate the damage. In addition to the chelation of DMBA metabolites to DNA, flow cytometry results revealed that oxidation was also a factor of DNA damage. The oxidative DNA damage could be removed by co-treating with $10 \mu \mathrm{M}$-genistein. Because no increased oxidative DNA repair was observed, suppression on the cytochrome enzymes appeared to be the underlying mechanism.

Cytochrome P450: Comet assay: 8-Oxo-guanine: Genistein

Polycyclic aromatic hydrocarbons (PAH) are commonly found in our environment, and they can be isolated from diesel exhaust, barbequed meat, tobacco smoke, overheated cooking oil, etc ${ }^{(1)}$. PAH are metabolised and transformed into DNAattacking electrophiles in the body. The significance of these environmental toxicants in breast cancer can be inferred from the increased presence of PAH-DNA adducts in human breast tumours ${ }^{(2)}$.

Cytochrome P450 (CYP) 1A1 and CYP1B1 enzymes are responsible for the biotransformation of procarcinogens to genotoxic moieties $\mathrm{PAH}^{(3,4)}$. The importance of these CYP1 enzymes in $\mathrm{PAH}$-induced carcinogenesis is implicated in two gene-knockout mouse results; benzo[ $a$ ]pyrene cannot induce CYP1A1 or cancer in aryl hydrocarbon receptor-null mice ${ }^{(5)}$, and lower cancer incidence was observed in 7,12dimethyl-benz $[a]$ anthracene (DMBA)-treated CYP1B1 knockout mice ${ }^{(6)}$.

The significance of the family of CYP1 enzymes in human breast cancer is not clear. Both tumour and normal tissues of the breast express CYP1A1 and CYP1B $1^{(7-9)}$. The inhibition of CYP1 enzymes appears to be beneficial in the prevention of DMBA-DNA adduct formation in vivo ${ }^{(10)}$ and in vitro ${ }^{(11)}$. Polymorphisms with higher activity of CYP1A1 appear to be a risk factor for breast cancer in African-Americans ${ }^{(12)}$; so are the polymorphisms of CYP1B1 in Asian women ${ }^{(13)}$.

Breast cancer is one of the most prevalent cancers in women. Asian countries have lower breast cancer incidences than the West; however, no difference in breast cancer incidence is found between Asian descendents and other women in America ${ }^{(14)}$. These observations suggest that environment may play a part in the aetiology of breast cancer, and soya consumption has been one of the major leads of investigation.

Because MCF-10A cells are non-tumorigenic, they are a better model than MCF-7 cells for chemopreventive study. In the present study, the effect of genistein on oxidative DNA damage induced by DMBA was investigated in these non-cancerous cells. It was postulated that genistein could protect against PAH-induced DNA damage.

\section{Materials and methods \\ Chemicals \\ ${ }^{3} \mathrm{H}$-labelled 7,12-dimethylbenz[ $a$ ]anthracene was obtained from Amersham Pharmacia Biotech UK Limited (Buckinghamshire,}

Abbreviations: CYP, cytochrome P450; DMBA, 7,12-dimethyl-benz[a $]$ anthracene; EROD, ethoxyresorufin- $O$-deethylase; 8-oxoG, 8-oxo-guanine; PAH, polycyclic aromatic hydrocarbons.

* Corresponding author: Dr Lai K. Leung, fax +852 26037732, email laikleung@cuhk.edu.hk 
UK). Other reagents, if not stated, were purchased from Sigma Chemicals (St Louis, MO, USA).

\section{Cell culture}

MCF-10A cells (American Tissue Culture Collection, Rockville, MD, USA) were routinely cultured in Roswell Park Memorial Institute (RPMI)-1640 media (Sigma Chemicals), supplemented with $10 \%$ fetal bovine serum (Invitrogen Life Technologies, Rockville, MD, USA) and antibiotics (50 U/ml penicillin, $50 \mu \mathrm{g} / \mathrm{ml}$ streptomycin), and incubated at $37^{\circ} \mathrm{C}$ and $5 \% \mathrm{CO}_{2}$. At $3 \mathrm{~d}$ before the experiment, the cultures were switched to RPMI-1640 phenol red-free media (Sigma Chemicals) and 5\% charcoal-dextran-treated fetal bovine serum (HyClone, Logan, UT, USA). Sub-confluent cell cultures were treated with DMBA and various concentrations of isoflavone with dimethylsulfoxide as the carrier solvent. The final concentration of the solvent was $0.1 \%(\mathrm{v} / \mathrm{v})$, and the control cultures received dimethylsulfoxide only.

\section{Measurement of 7,12-dimethyl-benz[a ] anthracene-DNA adduct formation}

The assay was performed as previously described ${ }^{(15)}$ and was performed in a six-well plate. Into each well $5 \times 10^{5}$ cells were placed and allowed to attach for $24 \mathrm{~h}$. Then they were treated with $\left[{ }^{3} \mathrm{H}\right] \mathrm{DMBA}(0 \cdot 1 \mu \mathrm{g} / \mathrm{ml})$. After $16 \mathrm{~h}$, cells were washed with cold PBS, trypsinised and pelleted. Cells were incubated on ice in nuclei-separating buffer (10 mM-2-amino-2-hydroxymethyl-propane-1,3-diol (Tris)- $\mathrm{HCl}$ (pH 7.5), 320 mM-sucrose, 5 mM-magnesium chloride and $1 \%$ Triton $\mathrm{X}-100)$ to separate the nuclei which were then separated from cell debris by centrifugation at $4000 \mathrm{~g}$ for $10 \mathrm{~min}$ at $4^{\circ} \mathrm{C}$. The nuclei were lysed by $400 \mu \mathrm{l}$ nuclei lysis buffer ( $1 \%$ SDS in $0.5 \mathrm{M}-$ Tris, $20 \mu \mathrm{m}$-EDTA and $10 \mathrm{~mm}-\mathrm{NaCl}, \mathrm{pH}$ 9) and then treated with $20 \mu \mathrm{l}$ proteinase $\mathrm{K}(20 \mathrm{mg} / \mathrm{ml})$ for $2 \mathrm{~h}$ at $48^{\circ} \mathrm{C}$. After that the samples were cooled at room temperature and residual proteins were salted out by the addition of $150 \mu \mathrm{l}$ saturated $\mathrm{NaCl}$. The samples were then subjected to centrifugation at $10000 \mathrm{~g}$ for $30 \mathrm{~min}$ at $4^{\circ} \mathrm{C}$. Genomic DNA was isolated from the supernatant fraction by ethanol precipitation and re-dissolved in autoclaved distilled water. DNA samples having an optical density $260 \mathrm{~nm}: 280 \mathrm{~nm}$ ratio larger than 1.9 are used for scintillation counting. Samples were mixed with $4 \mathrm{ml}$ cocktail in a vial and were subjected to scintillation counting.

\section{Comet assay}

A CometAssay ${ }^{\mathrm{TM}}$ Kit was ordered from Trevigen (Gaithersburg, MD, USA). Cells were placed in a six-well plate and allowed to attach for $24 \mathrm{~h}$. After treatment of drugs, cells were washed with PBS, trypsinised and pelleted. The cell pellet was re-suspended in PBS. Cells at $2 \times 10^{5}$ cells $/ \mathrm{ml}$ were combined with molten low-melting agarose at $42^{\circ} \mathrm{C}$ at $1: 10$. Of the above mixture, $75 \mu \mathrm{l}$ was pipetted and spread onto a CometSlide. The slide was placed at $4^{\circ} \mathrm{C}$ in the dark for $30 \mathrm{~min}$ for better adherence and then immersed in prechilled lysis solution and kept at $4^{\circ} \mathrm{C}$ in the dark for $60 \mathrm{~min}$. The slides were left in alkaline solution for $60 \mathrm{~min}$ at room temperature in the dark before electrophoresis. Alkaline electrophoresis was performed at $4{ }^{\circ} \mathrm{C}$ in the dark. Alkaline solution was poured to just cover the samples. The electrophoresis was performed for $30 \mathrm{~min}$ at $25 \mathrm{~V}$. The slides were rinsed with double-distilled water after electrophoresis and immersed in $70 \%$ ethanol for $5 \mathrm{~min}$. The slides were dried in air and then stained with $50 \mu \mathrm{l} \mathrm{SYBR}$ green. After staining, DNA samples are viewed by using a Nikon TE2000 microscope with relevant filters.

\section{Quantitative real-time PCR}

MCF-10A cells were seeded in a six-well plate for $1 \mathrm{~d}$ before treatment. The medium was removed, and cells were cultured in the presence of DMBA and genistein. After $24 \mathrm{~h}$ treatment, total RNA was extracted from the cells using TRIzol reagent (Invitrogen, Carlsbad, CA, USA). The concentration and purity of RNA were determined by absorbance at 260/ $280 \mathrm{~nm}$. First, DNA strands were synthesised from $3 \mathrm{mg}$ total RNA using oligo-dT primers and Moloney murine leukaemia virus RT (USB Corporation, Cleveland, OH, USA). Target fragments were quantified by real-time PCR, and a DNA Engine Opticon II (MJ Research, Inc., Waltham, MA, USA) was employed for this assay. Taqman/VIC minor groove binder probes and primers for CYP1A1, CYP1B1 and glyceraldehyde-3-phosphate dehydrogenase (Assay-onDemand $^{\mathrm{TM}}$ ) and real-time PCR Taqman Universal PCR Master Mix were all obtained from Applied Biosystems (Foster City, CA, USA). PCR reactions were set up as described in the protocol, which was validated by the manufacturer. Signals obtained for GAPDH were used as a reference housekeeping gene to normalise the amount of total RNA amplified in each reaction. Relative gene expression data were analysed using the $2^{-\Delta \Delta C T}$ method $^{(16)}$.

\section{Ethoxyresorufin-O-deethylase activity in intact cells}

The assay method was performed as previously described ${ }^{(17)}$. In brief, MCF-10A cells in ninety-six-well plates were treated with 2.5 $\mu \mathrm{M}$-DMBA and various concentrations of phytochemicals. The medium was then removed and the cells were washed twice by $100 \mu \mathrm{l}$ PBS. Ethoxyresorufin- $O$-deethylase (EROD) activities, which are indicative of CYP1 enzyme activities, were then carried out. To each well was added $100 \mu \mathrm{l}$ of $5 \mu \mathrm{M}$-ethoxyresorufin in PBS with $1.5 \mathrm{~mm}$-salicyclamide, which was followed by incubation at $37^{\circ} \mathrm{C}$ for $15 \mathrm{~min}$. The reaction was stopped by $100 \mu$ l of ice-cold methanol, and the resorufin generated was measured by a FLUOstar Galaxy microplate reader (BMG Labtechnologies Inc., Durham, NC, USA) with excitation of $544 \mathrm{~nm}$ and emission at $590 \mathrm{~nm}$.

\section{Oxidative DNA damage assay}

A fluorometric OxyDNA Assay Kit was obtained from Calbiochem (San Diego, CA, USA). MCF-10A cells were cultured in a six-well plate. After drug treatment, the cells were trypsinised, washed and suspended in Falcon culture tubes. The cells were fixed with $1 \mathrm{ml}$ of $70 \%$ ethanol and stored at $4^{\circ} \mathrm{C}$ overnight. After fixing, the cells were washed twice and re-suspended in blocking solution for $1 \mathrm{~h}$ at $37^{\circ} \mathrm{C}$. The cells 
were then incubated in fluorescein isothiocyanate (FITC)-conjugate solution in the dark for $1 \mathrm{~h}$ at room temperature. The cells were collected and re-suspended in fluorescenceactivated cell sorting (FACS) fluid. The amount of oxidised DNA was then determined by FACSORT flow cytometry with a FITC filter, and 10000 cells were enumerated for each run.

\section{Preparation of oligonucleotide substrates}

The 19-mer oligonucleotide substrates required for activity assays were synthesised and purified as previously described ${ }^{(18)}$. The sequences are as follows:

\section{Chang 179, 5'-GCAGAAGGCOAATTCCTCG-3'; \\ Chang68C, 5'-CCGAGGAATTCGCCTTCTG-3',}

where $O$ represents 8 -oxo-guanine (8-oxoG) and the bases at the matched sites are underlined.

Heteroduplexes containing C/8-oxoG were constructed by annealing Chang68C with Chang179. One pmol of annealed duplexes was labelled at the $3^{\prime}$ or $5^{\prime}$ end as described by $\mathrm{Lu}^{(19)}$ and $\mathrm{Lu}$ et al. ${ }^{(20)}$. After being filled in with the Klenow fragment of DNA polymerase I, the resulting bluntend duplex DNA was $20 \mathrm{bp}$ in length.

\section{Assay of oxidative DNA repair activity}

Oxidative DNA repair measured as C/8-oxoG-DNA glycosylase activity was performed according to Hazra et al. ${ }^{(21)}$. A $25 \mu \mathrm{l}$ DNA binding reaction contained $20 \mu \mathrm{g}$ protein, $25 \mathrm{~mm}$ HEPES ( $\mathrm{pH} 7 \cdot 6$ ), $50 \mathrm{mM}-\mathrm{KCl}, 2.5 \mathrm{~mm}$-EDTA, 2 mM-dithiothreitol, $2.5 \%$ glycerol and $3.6 \mathrm{fmol}$ of $\mathrm{C} / 8$-oxoG-containing labelled DNA. The reactions were incubated at $37^{\circ} \mathrm{C}$ for $1 \mathrm{~h}$, terminated by phenol-chloroform extraction and ethanol precipitation. Samples were dissolved in $3 \mu$ l of sequencing dye. After being heated at $90^{\circ} \mathrm{C}$ for $3 \mathrm{~min}$, samples were resolved on a $14 \%$ polyacrylamide $-8 \cdot 3 \mathrm{M}$-urea sequencing gel and analysed by autoradiograph.

\section{Statistical analysis}

A Prism ${ }^{\circledR} 3.0$ (GraphPad Software, Inc., San Diego, CA, USA) software package was utilised for statistical analysis. The results of the present study were compared by ANOVA and Bonferroni's method for multiple comparisons. The level of significance was set at $P<0.05$.

\section{Results}

7,12-Dimethyl-benz[a Janthracene-induced cytochrome P450 $1 A 1$ and $1 B 1$ mRNA expressions suppression by genistein

The expression of CYP1A1 and CYP1B1 was induced by DMBA by about 116-fold and 6-fold respectively. At $1 \mu \mathrm{M}$, genistein significantly reduced DMBA-induced CYP1A1 expression by $60 \%$ (Fig. 1), while $5 \mu \mathrm{M}$-genistein reduced DMBA-induced CYP1B1 expression by $30 \%$ (Fig. 2).

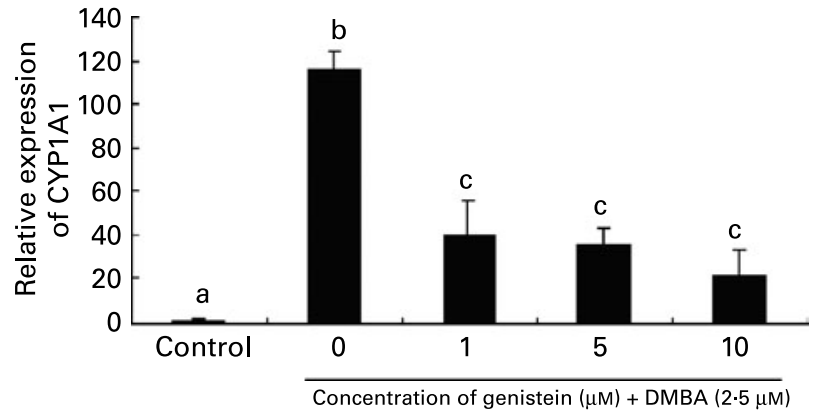

Fig. 1. Effect of genistein on 7,12-dimethyl-benz[a]anthracene (DMBA)induced cytochrome P450 (CYP) 1A1 expression. MCF-10A cells were treated with $2.5 \mu \mathrm{M}$-DMBA and genistein and cultured for $24 \mathrm{~h}$. mRNA expression of CYP1A1 was quantified by real-time PCR. Values are means $(n 3)$, with standard deviations represented by vertical bars. One-way ANOVA revealed that means are significantly $(P<0.05)$ different, and a post hoc ranking test indicated that $\mathrm{b}>\mathrm{c}>\mathrm{a}$.

\section{Reduction of 7,12-dimethyl-benz[a ] anthracene-induced} ethoxyresorufin-O-deethylase activities by genistein

DMBA induced EROD activity by 3 - or 4-fold. Figure 3 shows that $1 \mu \mathrm{M}$-genistein reduced DMBA-induced EROD activity by about $50 \%$. At 5 and $10 \mu \mathrm{M}$, genistein further reduced DMBA-induced EROD activity by about 65 and $75 \%$ respectively.

Reduction of binding of 7,12-dimethyl-benz[a ]anthraceneDNA in MCF-10A cells by genistein

DMBA could intercalate DNA and causes DNA damage. Figure 4 shows that genistein could also reduce DMBADNA adduct in MCF-10A cells. At 1 and $5 \mu \mathrm{M}$, genistein could reduce DNA adduct formation by about $35 \%$, while $10 \mu \mathrm{M}$-genistein could reduce the formation by $45 \%$.

DNA strand break generated by 7,12-dimethyl-

benz[a ]anthracene in MCF-10A cells moderated by genistein

Cells treated with DMBA or co-treated with $0 \cdot 1$ or $1 \mu \mathrm{M}$ of the phytochemical showed comparable percentages of intact cells

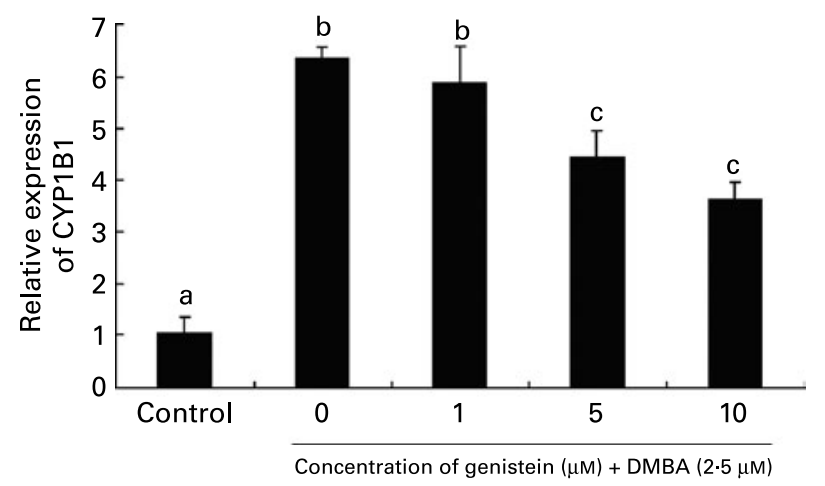

Fig. 2. Effect of genistein on 7,12-dimethyl-benz[a]anthracene (DMBA)induced cytochrome P450 (CYP) 1B1 expression. MCF-10A cells were treated with $2.5 \mu \mathrm{M}$-DMBA and genistein and cultured for $24 \mathrm{~h}$. mRNA expression of CYP1B1 was quantified by real-time PCR. Values are means $(n 3)$, with standard deviations represented by vertical bars. One-way ANOVA revealed that means are significantly $(P<0.05)$ different, and a post hoc ranking test indicated that $\mathrm{b}>\mathrm{c}>\mathrm{a}$. 


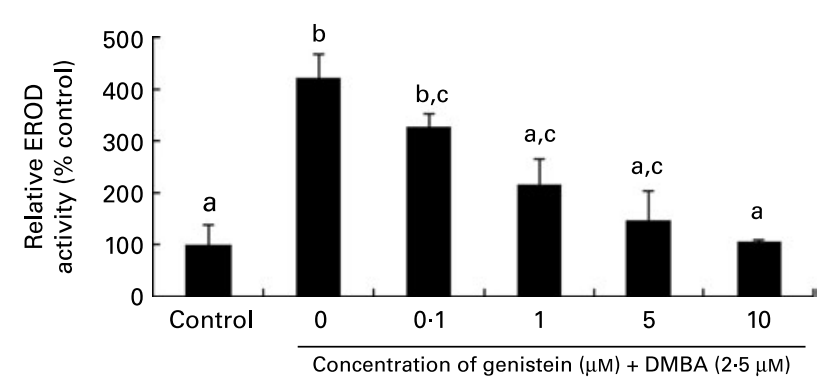

Fig. 3. Ethoxyresorufin-O-deethylase (EROD) activity in cells treated with genistein and 7,12-dimethyl-benz[a]anthracene (DMBA). MCF-10A cells were seeded in ninety-six-well culture plates and treated with $2.5 \mu \mathrm{M}$-DMBA and genistein. After a $24 \mathrm{~h}$ treatment, the cells were assayed for EROD activity. Values are means ( $n 3)$, with standard deviations represented by vertical bars. One-way ANOVA revealed that means are significantly $(P<0.05)$ different, and a post hoc ranking test indicated that $\mathrm{b}>\mathrm{c}>\mathrm{a}$

which were significantly lower than control (Fig. 5). The percentage of intact cells in DMBA co-treated with 5 or $10 \mu \mathrm{M}$-genistein was similar to control.

\section{Alleviation of 7,12-dimethyl-benz[a ]anthracene-induced oxidative DNA damage by genistein}

Flow cytometry showed that a right shift of fluorescence occurred upon 2.5 $\mu \mathrm{M}$-DMBA treatment (Fig. 6(A)). This result indicated that the treatment increased the amount of 8 -oxoG in DNA. The co-treatment with $0 \cdot 1$ and $1 \mu \mathrm{M}$-genistein had little effect on the shifted fluorescence (Fig. 6(B) and (C)). However, $10 \mu \mathrm{M}$-genistein could bring the shifted florescence back to the control state (Fig. 6(D)). Moreover, various treatments in the study did not seem to affect the cell cycle.

\section{Effect of 7,12-dimethyl-benz[a] anthracene and co-treatment} with genistein on oxidative DNA repair

Glycosylase activity is crucial in repairing DNA damage. In the DMBA treatment group, there was no indication of increased activity in 8-oxoG glycosylase compared with control. In addition, administration of genistein at the dosages ranging from $0 \cdot 1$ to $10 \mu \mathrm{M}$ did not elevate the repairing capacity (data not shown). Therefore, the reduced 8-oxoG in

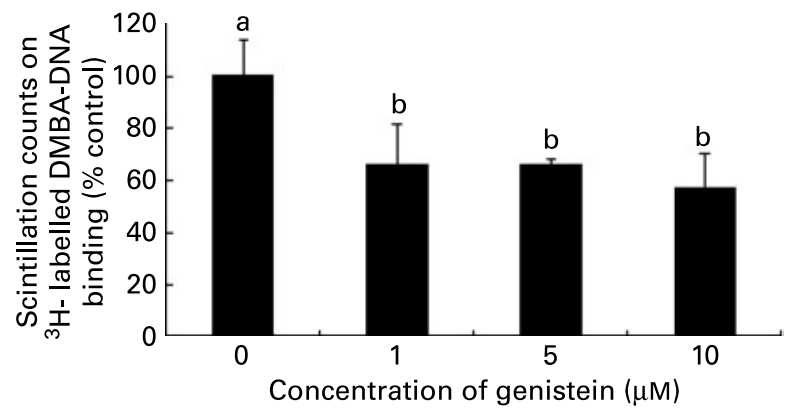

Fig. 4. Genistein decreased 7,12-dimethyl-benz[a]anthracene (DMBA)-DNA binding. MCF-10A cells were seeded in six-well culture plates and treated with genistein and ${ }^{3} \mathrm{H}$-labelled DMBA. After a $24 \mathrm{~h}$ treatment, genomic DNA was extracted and the DMBA-DNA lesions were determined by scintillation counting. Values are means $(n 3)$, with standard deviations represented by vertical bars. One-way ANOVA revealed that means are significantly $(P<0.05)$ different, and a post hoc ranking test indicated that $\mathrm{a}>\mathrm{b}$

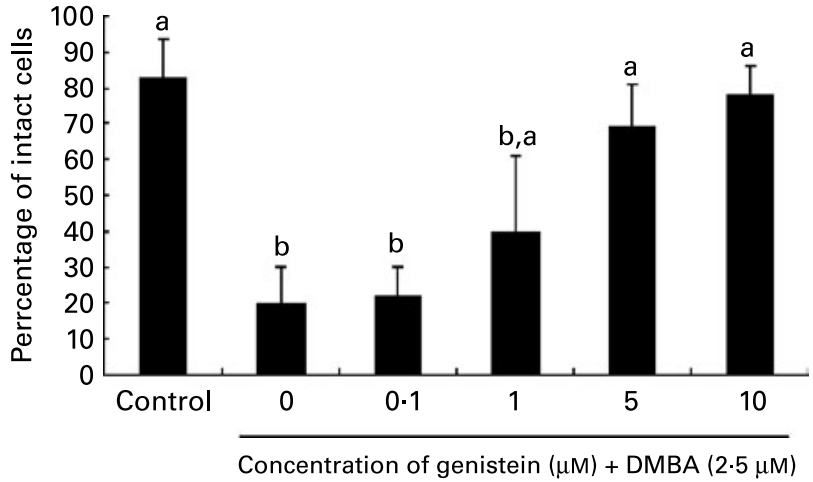

Fig. 5. Comet-forming activity in cells treated with 7,12-dimethyl-benz[a]anthracene (DMBA) and genistein. MCF-10A cells were seeded in six-well culture plates and treated with $2.5 \mu \mathrm{M}$-DMBA and genistein. After a $72 \mathrm{~h}$ treatment, cells were disaggregated with trypsin/EDTA before incorporation into the comet assay as described in Materials and methods. Cells with a fragmented DNA tail were regarded as damaged cells while those which did not possess a tail were regarded as intact cells. Values are means $(n 3)$, with standard deviations represented by vertical bars. One-way ANOVA revealed that means are significantly $(P<0.05)$ different, and a post hoc ranking test indicated that $\mathrm{a}>\mathrm{b}$.

the co-treatment with genistein as shown above was not the result of increased repair capacity.

\section{Discussion}

In the present study, we demonstrated that genistein could reduce oxidative DNA damage induced by DMBA. Although the system for repairing 8-oxoG was not induced, the suppression on CYP1 expressions might reduce the free radical generation and decrease the cellular oxidative stress.

Genistein has been a controversial figure in serving as a chemopreventive agent of the breast. It is well established that the phyto-oestrogen induces oestrogen receptor-positive breast cell proliferation. In addition, its metabolite, orobol or $5,7,3^{\prime}, 4^{\prime}$-tetrahydroxyisoflavone, can produce oxidative DNA damage $^{(22)}$. Genistein is considered as a pro-oxidant in this regard. In the present study, we employed a non-cancerous cell system to verify the phyto-oestrogen's effect on DNA damage. The same phytocompound was not only able to block oxidative DNA damage caused by DMBA, but it could also reduce DNA strand break. This sharp contrast can be explained by the nature of the model systems. The former study measured 8-oxoG in calf thymus DNA generated from incubating with orobol, NADH and $\mathrm{Cu}$ (II). Genistein can also act on oestrogen receptors and apoptosis in breast cancer cells as reviewed by Leung et al. ${ }^{(23)}$.

The comet assay, which quantifies total cellular DNA damage, revealed that genistein offered a protective effect on DNA integrity against DMBA assault in the present study. As reviewed by Xue \& Warshawsky ${ }^{(24)}$, PAH may induce multifaceted DNA damage. It can be metabolised into isomers of diolepoxide and radical cations. These diol-epoxides and radical cations of PAH may bind to DNA and form adducts. In addition, PAH-o-quinone and reactive oxygen species may also be generated in an alternative metabolic pathway. The cytochrome p450 enzymes, CYP1A1, 1B1 and 1A2, are responsible in generating those proximate carcinogens. Nevertheless, CYP1A1 and 1B1 are predominantly expressed in extrahepatic tissues, including 
(A)
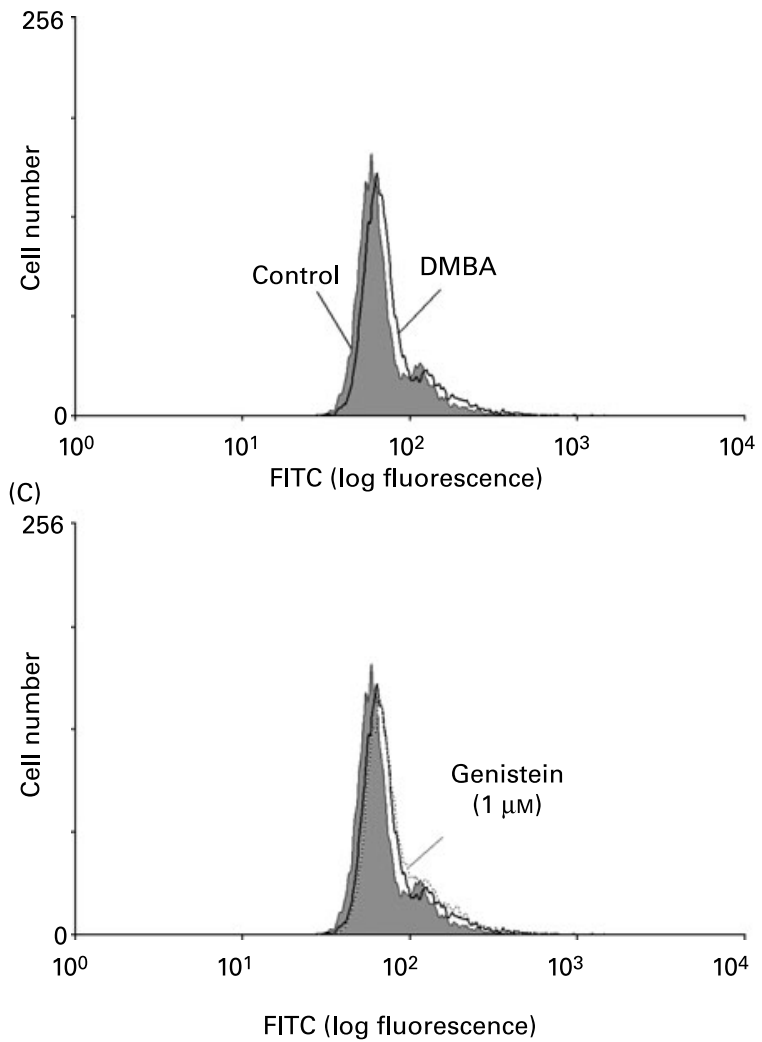

(B)
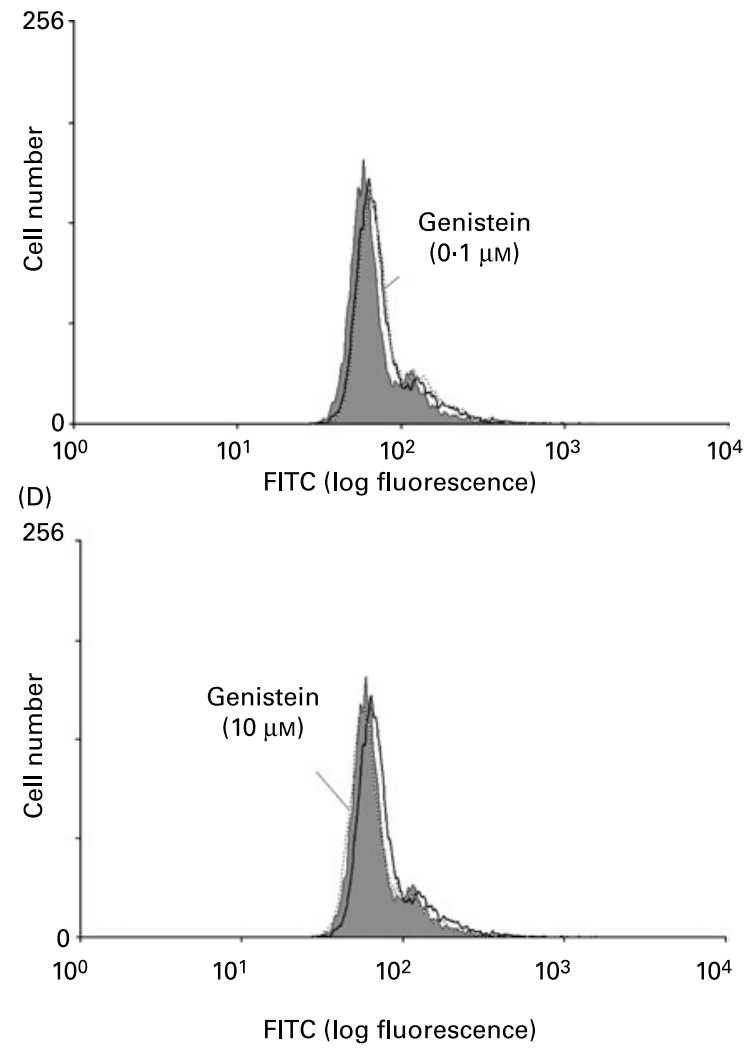

Fig. 6. Oxidative DNA damage in 7,12-dimethyl-benz[a]anthracene (DMBA) and genistein-co-treated MCF-10A cells. MCF-10A cells were seeded in six-well culture plates and treated with $2.5 \mu \mathrm{M}$-DMBA and genistein for $24 \mathrm{~h}(\mathrm{~A})$. Cells were disaggregated with trypsin/EDTA, fixed and processed for flow cytometry. Control cells $(-)$ with oxidised DNA conjugated to fluorescein isothiocyanate (FITC) are shaded grey. The conjugated profile of cells treated with DMBA (...) shifted to the right. Concentrations of 0.1 (B), 1 (C) and 10 (D) $\mu \mathrm{M}$-genistein (- - -) were co-adminstrated in the cultures. The geometric means of control, DMBA treatment, DMBA-0.1 $\mu \mathrm{M}$-genistein co-treatment, DMBA-1 $\mu \mathrm{M}$ genistein co-treatment and DMBA-10 $\mu \mathrm{M}$-genistein co-treatment are $69,79,82,84$ and 68 units of light intensity, respectively.

the breast. Similar to a previous study performed in MCF-7 cells ${ }^{(15)}$, genistein in the present investigation could suppress the expression of CYP1A1 and CYP1B1 induced by DMBA in the non-tumorigenic MCF-10A cells. As the initial steps of diol-epoxide metabolism required CYP1 enzymes, decreased CYP1 expression could produce a lesser amount of diol-epoxides. Subsequent PAH-o-quinone formation and the associated reactive oxygen species generation could also be reduced.

Animal studies have elicited conflicting results on the protective roles of genistein against breast cancer. Pubertal administration of genistein reduced breast cancer incidence in rats ${ }^{(25,26)}$, while soya given after weaning has been proven to be ineffective on carcinogenesis induced by $\mathrm{DMBA}^{(27)}$. Gallo et al. ${ }^{(28)}$ have shown that genistein reduces the percentage of poorly differentiated tumours. In a recent study, genistein is effective in delaying the latency of mammary tumour development in a spontaneous carcinogenesis model $^{(29)}$. In contrast, genistein has been demonstrated to increase DMBA-induced mammary tumours in oestrogen receptor- $\alpha$-intact mice and encourages the proliferation of MCF-7 tumours in athymic mice ${ }^{(30)}$ and Sprague-Dawley rats ${ }^{(31)}$. A recent report has demonstrated that administration of genistein or daidzein alone does not result in significant mutagenic or carcinogenic changes in mammary tissues in ovariectomised or ovary-intact rats; however, administering genistein and daidzein in a mixture reduced DMBA-induced mutagenicity and carcinogenicity in mammary tissues significantly ${ }^{(32)}$. These reports have shown inconsistent results but the genistein exposure at different stage in the life cycle or carcinogenesis appears to be a critical factor.

In summary, we first demonstrated that oxidative DNA damage induced by PAH was prevented by the soya isoflavone genistein in a non-cancerous breast cell line in the present study. These findings reinforce the notion that the soya isoflavone may block the initiation steps in breast carcinogenesis.

\section{Acknowledgements}

All authors contributed to the research work of the present study, and funding of the study was provided by the Chinese University of Hong Kong. There are no conflicts of interest for the present study.

\section{References}

1. International Agency for Research on Cancer (1983) Polynuclear aromatic compounds, part 1. Chemical, environmental and experimental data. In IARC Monographs on the Evaluation of the Carcinogenic Risk of Chemicals to Humans, vol. 32. Lyon, France: International Agency for Research on Cancer. 
2. Li D, Wang M, Dhingra K \& Hittelman WN (1996) Aromatic DNA adducts in adjacent tissues of breast cancer patients: clues to breast cancer etiology. Cancer Res 56, 287-293.

3. Dertinger SD, Lantum HB, Silverstone AE \& Gasiewicz TA (2000) Effect of 30-methoxy-40-nitroflavone on benzo[ $a$ ]pyrene toxicity. Aryl hydrocarbon receptor-dependent and -independent mechanisms. Biochem Pharmacol 60, 189-196.

4. Safe S (2001) Molecular biology of the Ah receptor and its role in carcinogenesis. Toxicol Lett 120, 1-7.

5. Shimizu Y, Nakatsuru Y, Ichinose M, Takahashi Y, Kume H, Mimura J, Fujii-Kuriyama Y \& Ishikawa T (2000) Benzo[a]pyrene carcinogenicity is lost in mice lacking the aryl hydrocarbon receptor. PNAS 97, 779-782.

6. Buters JT, Sakai S, Richter T, Pineau T, Alexander DL, Savas U, Doehmer J, Ward JM, Jefcoate CR \& Gonzalez FJ (1999) Cytochrome P450 CYP1B1 determines susceptibility to 7,12dimethylbenz $[a]$ anthracene-induced lymphomas. PNAS 96, 1977-1982.

7. Spink BC, Fasco MJ, Gierthy JF \& Spink DC (1998) 12-O-Tetradecanoyl-phorbol-13-acetate upregulates the Ah receptor and differentially alters CYP1B1 and CYP1A1 expression in MCF-7 breast cancer cells. J Cell Biochem 70, 289-296.

8. Spink DC, Spink BC, Cao JQ, DePasquale JA, Pentecost BT, Fasco MJ, Li Y \& Sutter TR (1998) Differential expression of CYP1A1 and CYP1B1 in human breast epithelial cells and breast tumor cells. Carcinogenesis 19, 291-298.

9. Iscan M, Klaavuniemi T, Coban T, Kapucuoglu N, Pelkonen O \& Raunio H (2001) The expression of cytochrome P450 enzymes in human breast tumours and normal breast tissue. Breast Cancer Res Treat 70, 47-54.

10. MacDonald CJ, Ciolino HP \& Yeh GC (2001) Dibenzoylmethane modulates aryl hydrocarbon receptor function and expression of cytochromes P50 1A1, 1A2, and 1B1. Cancer Res 61, 3919-3924.

11. Kleiner HE, Vulimiri SV, Reed MJ, Uberecken A \& DiGiovanni J (2002) Role of cytochrome P450 1A1 and 1B1 in the metabolic activation of 7,12-dimethylbenz- $[a]$ anthracene and the effects of naturally occurring furanocoumarins on skin tumor initiation. Chem Res Toxicol 15, 226-235.

12. Taioli E (1999) International collaborative study on genetic susceptibility to environmental carcinogens. Cancer Epidemiol Biomarkers Prev 8, 727-728.

13. Zheng W, Xie DW, Jin F, Cheng JR, Dai Q, Wen WQ, Shu XO \& Gao YT (2000) Genetic polymorphism of P450 1B1 and risk of breast cancer. Cancer Epidemiol Biomarkers Prev 9, 147-150.

14. Ziegler RG, Hoover RN, Pike MC, et al. (1993) Migration patterns and breast cancer risk in Asian-American women. $J$ Natl Cancer Inst 85, 1819-1827.

15. Chan HY \& Leung LK (2003) A potential protective mechanism of soya isoflavones against 7,12-dimethylbenz $[a]$ anthracene tumour initiation. Br J Nutr 90, 457-465.

16. Livak KJ \& Schmittgen TD (2001) Analysis of relative gene expression data using real-time quantitative PCR and the 2(-delta delta C(T)) method. Methods 25, 402-408.

17. Ciolino HP \& Yeh GC (1999) Inhibition of aryl hydrocarbon induced cytochrome P-450 1A1 enzyme activity and CYP1A1 expression by resveratrol. Mol Pharmacol 56, 760-767.
18. Lu A-L, Yuen DS \& Cillo J (1996) Catalytic mechanism and DNA substrate recognition of Escherichia coli MutY protein. J Biol Chem 271, 24138-24143.

19. Lu A-L (2000) Repair of A/G and A/8-oxoG mismatches by MutY adenine DNA glycosylase. In DNA Repair Protocols, pp. 3-16 [P Vaughan, editor]. Totowa, NJ: Humana Press Inc.

20. Lu A-L, Tsai-Wu JJ \& Cillo J (1995) DNA determinants and substrate specificities of Escherichia coli MutY. J Biol Chem 270, 23582-23588.

21. Hazra TK, Izumi T, Maidt L, Floyd RA \& Mitra S (1998) The presence of two distinct 8-oxo-guanine repair enzymes in human cells: their potential complementary roles in preventing mutation. Nucleic Acids Res 26, 5116-5122.

22. Murata M, Midorikawa K, Koh M, Umezawa K \& Kawanishi S (2004) Genistein and daidzein induce cell proliferation and their metabolites cause oxidative DNA damage in relation to isoflavone-induced cancer of oestrogen-sensitive organs. Biochemistry 43, 2569-2577.

23. Leung LK, Yuen YM, Leung HY \& Wang Y (2005) Dietary soya isoflavones and breast carcinogenesis: a perspective from a cell-culture model. Nutr Res Rev 18, 202-211.

24. Xue W \& Warshawsky D (2005) Metabolic activation of polycyclic and heterocyclic aromatic hydrocarbons and DNA damage: a review. Toxicol Appl Pharmacol 206, 73-93.

25. Hilakivi-Clarke L, Onojafe I, Raygada M, Cho E, Skaar T, Russo I \& Clarke R (1999) Prepubertal exposure to zearalenone or genistein reduces mammary tumorigenesis. Br J Cancer $\mathbf{8 0}$, $1682-1688$.

26. Lamartiniere CA, Cotroneo MS, Fritz WA, Wang J, MentorMarcel R \& Elgavish A (2002) Genistein chemoprevention: timing and mechanisms of action in murine mammary and prostate. J Nutr 132, 552S-558S.

27. Appelt LC \& Reicks MM (1999) Soy induces phase II enzymes but does not inhibit dimethylbenz $[a]$ anthraceneinduced carcinogenesis in female rats. $J$ Nutr 129, $1820-1826$.

28. Gallo D, Giacomelli S, Cantelmo F, et al. (2001) Chemoprevention of DMBA-induced mammary cancer in rats by dietary soy. Breast Cancer Res Treat 69, 153-164.

29. Jin Z \& MacDonald RS (2002) Soy isoflavones increase latency of spontaneous mammary tumour in mice. $J$ Nutr 132, $3186-3190$.

30. Ju YH, Allred CD, Allred KF, Karko KL, Doerge DR \& Helferich WG (2001) Physiological concentrations of dietary genistein dose-dependently stimulate growth of estrogen-dependent human breast cancer (MCF-7) tumors implanted in athymic nude mice. J Nutr 131, 2957-2962.

31. Allred CD, Allred KF, Ju YH, Clausen LM, Doerge DR, Schantz SL, Korol DL, Wallig MA \& Helferich WG (2004) Dietary genistein results in larger MNU-induced, oestrogendependent mammary tumors following ovariectomy of Sprague-Dawley rats. Carcinogenesis 25, 211-218.

32. Manjanatha MG, Shelton S, Bishop ME, Lyn-Cook LE \& Aidoo A (2006) Dietary effects of soy isoflavones daidzein and genistein on 7,12-dimethylbenz $[a]$-anthracene-induced mammary mutagenesis and carcinogenesis in ovariectomized Big Blue transgenic rats. Carcinogenesis 27, 2555-2564. 